body (for a primitive tribe is a close corporation of interbreeding individuals) by what is taking place in the modern business world. We may take our illustration from our banking businesses. Ever since Darwin's day there has been taking place, just as happened in recent millennia in the human world, a tendency to the creation of an ever-increasing size of the evolutionary units; local banks have been amalgamated, and local amalgamations have been swallowed by central concerns, so that now only a limited number of great competing units survive, which units we may compare to the great nations of to-day. These large corporations, being managed by self-electing directorates, are run, as a recent writer points out (The Times, "Private Enterprise", September 18 and 19,1942 ), for the benefit not of the whole British community but for a section of it. The problem is how the whole community can be benefited and yet be free from the evils, or risks, of monopoly.

Nature had, and has, to face the same problem in the evolution of mankind. The directorate she instituted for her purpose is that combination of qualities we call 'human nature', in which cooperative and competitive inborn or instinctive tendencies work for the good of the community or tribe as a whole. To quote Darwin once more (p. 190), "The social instincts ... no doubt were acquired by man, as by the lower animals for the good of the community".

\section{THE EXPLOITATION OF MINERALS IN RELATION TO NATIONAL AND WORLD PLANNING*}

\section{By DR. L. DUDLEY STAMP}

$\mathrm{A}$ LL minerals are won by what used to be called 'robber economy'. Man has no control over the location of minerals: his efforts are directed towards the discovery and subsequent winning of deposits the position of which is dependent upon the geological structure of the earth, or towards the utilization of deposits not previously regarded as 'economic'. Once any given deposit is exhausted it is not replenished.

Thus the social and economic consequences of the extractive industries are entirely different from those which result from industries connected with either the animal or vegetable kingdoms. In those cases, provided adequate care is taken, Nature replenishes the stores year by year and the dependent industries are afforded a marked degree of permanence. By the limited nature of the resources on which they depend, mineral industries, whether merely extraction or processing, or secondary industries based thereon, are essentially impermanent.

It is of considerable importance to distinguish between two groups of economic minerals. In the first place, there are those which occur in limited supply and where the object of mining is to remove all, or as much as is economically feasible, of the mineral. Into this category come oil, coal, iron ore (at least above a certain metal content). and most metalliferous ores. In the second place, there are

- Paper read at the Conference on Mineral Resources and the Atlantic Charter arranged by the Division for the Social and International Relations of Science of the British Association on July 25 . those minerals which occur in such abundance that only parts of the available deposits are ever likely to be worked. Into this category come limestone (including chalk) for lime and cement, clay for bricks and tiles, slate, building-stones, road metal, sand and gravel.

In the international planning of mineral exploitation it is the first group which is concerned : the rocks and minerals of the second group are of the greatest importance, but nationally rather than internationally. In the minerals of the first group there is little choice in the siting of the works; in the minerals of the second group it is possible to plan the actual areas of working to a considerable extent-they are usually dictated primarily on economic grounds, especially in relation to transport costs, but where necessary may be planned in accordance with requirements of the national planning or the location of industry, the conservation of agricultural land, the preservation of amenities and other relevant factors.

Restricting attention to the minerals of the first group, those of which the object is to remove the whole or as much as possible, a definite cycle is associated with the working. This is, briefly, exploration, exploitation and exhaustion. With exploration and the early stages of exploitation comes a very rapid development, an influx of population, a spate of building and often of extravagant expenditureindeed all the conditions associated with a 'mining boom' whether it be a gold rush, an oil boom, or simply the development of a new coalfield. The period of relatively steady exploitation may be short (as in the case of alluvial gold or tin) or it may be long-even running into a century or more (as in the case of a coalfield). If it is long, then social and economic conditions become stabilized, substantial towns are built and the whole community may go so far as to forget that its existence is primarily dependent on the exploitation of a mineral deposit. This is the position reached in many of the older coalfields of Britain. The period of exhaustion or approaching exhaustion is one of serious and inevitable maladjustments often resulting in much human suffering and misery, and which calls for careful thought and action-it cannot be left to right itself.

Thus the recognition of the right of the nations of the world to share the world's mineral resources carries with it the obligation of those nations to accept responsibility and to share the burden of whatever social and economic readjustments may be needed. There is, in other words, an obligation to safeguard the interests of human beings both during and after the exploitation of the minerals.

Most of the problems which arise, and some of the readjustments, can be illustrated, though on a small scale, in the British Isles.

(a) Tin has been won in Cornwall and the southwest since pre-Roman times. Exploitation reached its peak some seventy years ago and resulted in a large number of mines with their conspicuous pithead gear widely scattered over the wilder parts of the county. At least two not inconsiderable towns, Camborne and Redruth, grew up dependent primarily on mining. To-day most of the deposits are sufficiently near exhaustion that in pre-war years their exploitation had become uneconomic. As a mine approaches the later stage of its career, there is little money left after running costs have been met and, when the mine fails, none at all to remove the old gear and buildings, which thus become unsightly ruins marring 
the countryside. In the case of the Cornish tin mines, much of the skill, experience and capital released from local mines was transferred abroad-many Malayan companies are offshoots of Cornish parents and are often staffed by Cornish miners. Camborne and Redruth came to depend on foreign investments - one solution, perhaps a rare one, of this difficult problem.

(b) Lead was won by the Romans and at this moment is being worked again in Cumbria and elsewhere. The position is much as with tin, except that there is here an additional complication: that of noxious effluents and poisonous fumes from smelting. The first promise often to destroy freshwater life, including valuable fisheries; the second may ruin agriculture as well as natural vegetation for miles round. The aftermath is terrible. The same is true of the extraction of salt, gypsum, and the associated heavy chemical industries.

(c) Iron ore. The once flourishing iron industry of the Weald has gone, leaving little or no trace; the iron industry of the South Wales coalfield is more recent and has left behind a solid core, in peace-time conditions at least, of unemployment. In the Black Country, the evils have been mitigated by the switch over to other industries. The latest phase of maladjustment in the iron industry is seen in Northamptonshire, where thousands of acres of good agricultural land are being left, after removal of the ore, a stony desert of steep ridges and valleys useless to man and beast and affording little hope even for useful vegetation or afforestation. Yet a limited expenditure, with the aid of modern levelling machinery of the type now being used on aerodromes, could restore this land to usefulness.

(d) Slate quarries, chalk quarries, and other scattered surface workings, including those for gravel and sand, raise especially questions of amenity and the need for regulation, including definite directions towards the location of industry, in national planning.

(e) Coalfields afford examples of the problems raised by mineral working at their most dificult. A coalfield develops slowly, and its development gives rise to such permanent towns and villages that the subsequent problems of readjustment are extremely difficult. So rooted are the human beings that the solution of the problem has tended to be, not the 'scrapping' of the settlements-which is the logical course-and the removal of the people, but the deliberate effort to bring industry of new types to the pool of labour thus available.

T'hese examples, drawn from Britain, are sufficient to illustrate the far-reaching character of the human and economic problems raised by the apparently simple proposition of sharing the world's mineral resources. It would seem that three principles emerge :

(1) Mineral exploitation inevitably results in a need for restoration, whether it be of land or of the social structure of the community.

(2) This restoration should be obligatory on those, whether nations or individuals, who derive benefit from the working of the minerals.

(3) In the latter stages of mineral exploitation there is never a surplus of money, and therefore there should be some provision, comparable to an amortization insurance, made when the industry is flourishing, for use in the later stages for the work of restoration and rehabilitation.

\section{A STUDY OF ACCIDENTS}

$\mathrm{E}^{\mathrm{A}}$ MERGENCY REPORT No. 3 of the Industrial Health Research Board* is concerned with the problem of accidents, always important but still more so in war-time, when many circumstances combine to increase the risk of accidents. There is a tendency on the part of many people to accept accidents as inevitable happenings; one has only to recall the indifference to road accidents before the War to realize this. For some time now, efforts have been made to render the environment in which the industrial worker spends his working time safer; the legal aspect is embodied in the Factories Act and the Ministry of Labour Regulations, while advice is given by factory inspectors and the Royal Society for the Prevention of Accidents.

The report on accidents falls into two parts: the first part concerns itself with the general factors likely to affect all workers ir different degrees; the second part deals with the individual differences which result in reactions which are not uniform.

\section{General Factors affecting the Incidence of Accidents}

(1) Hours of work. During the War of 1914-18 investigations showed that unduly long hours led to an increase in the accident-rate, and there is evidence that fatigue was largely responsible. In war-time longer working hours are necessary, but there comes a point past which it is no longer profitable to let people work. Fatigue not only reduces the speed and accuracy of muscular movements, but also affects mental alertness.

(2) Heating and ventilation. The number of cuts and minor accidents increases with temperatures much above or below the range of $65-69^{\circ} \mathrm{F}$. Where processes generate much radiant heat the worker should be protected. Adequate ventilation should not be regarded merely as a side issue.

(3) Lighting. Lighting so inadequate that the worker cannot see his work effectively is a contributory cause of accidents. Too great a variation in lighting must also be avoided. Natural lighting, that is, daylight, is ideal when there is enough of it.

(4) Speed. Speed of production is a frequent cause of accidents, and since it is necessary in modern industry, care must be taken that machines are not moving too quickly, nor workers put on to speeds to which they cannot adjust themselves.

(5) Inexperience and age. Both these conditions are related to accidents, but are independent. People, whatever may be their age, if inexperienced at industrial work, are known to have a higher accidentrate than a similar group of experienced workers. Also young people, whether experienced or not, are more liable to have accidents than older people, partly because they are less responsible and partly because they have less control over their muscles. Therefore there should be adequate training for beginners, whether young or not, and adequate supervision for the young.

(6) Fitness for the work. Quite apart from physical unfitness a worker may be mentally ill-adapted to his work. There is evidence that workers of high mental ability, if employed on repetitive work demanding little thought, become bored, which state

* The Personal Factor in Accidents. Emergency Report No. 3. Industrial Health Research Board. 1942. 4d. net. 